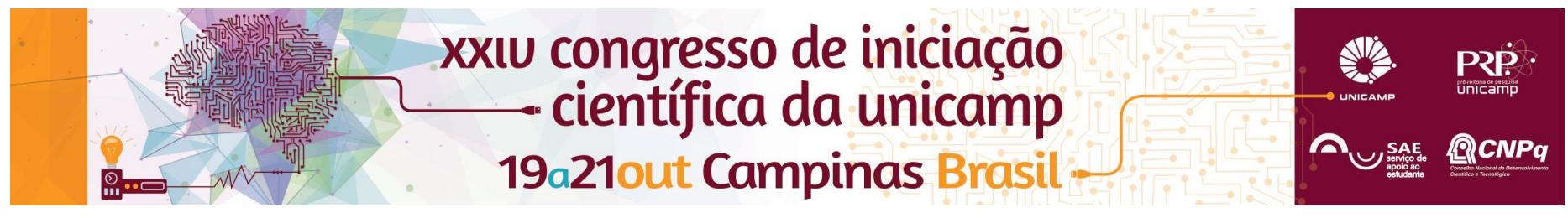

\title{
INFLUÊNCIA DA SÍLICA DA CASCA DO ARROZ (SCA) NAS PROPRIEDADES DOS COMPÓSITOS CIMENTÍCIOS
}

\author{
Caio Batista Carra*, Carlos Eduardo Marmorato Gomes.
}

\begin{abstract}
Resumo
O uso da sílica da casca do arroz como material pozolânico em compósitos cimentícios tem sido pesquisado ao longo dos anos, principalmente após o desenvolvimento de novas tecnologias que possibilitam obter uma sílica amorfa condizente com as exigências do mercado de construção civil. Portanto, o presente projeto de iniciação científica objetivou apresentar ao aluno de graduação novos conceitos de sustentabilidade aplicada na construção civil por meio do uso da sílica da casca doa arroz (SCA), demonstrando ser possível o incremento das principais propriedades mecânicas da argamassa de cimento Portland. Foram investigados além da resistência mecânica das argamassas, também, sua influência no tempo de pega do cimento e consistência da argamassa cimentícia.
\end{abstract}

Palavras-chave: sílica da casca de arroz, pozolana, sustentabilidade.

\section{Introdução}

O estudo da cinza de casca de arroz como material pozolânico não é recente e tem sido pesquisado há mais de 40 anos. Esta tecnologia teve maior estímulo a partir do desenvolvimento do concreto de alto desempenho (CAD) e o emprego das sílicas oriundas da fabricação das ligas de ferro silício e do silício metálico. Atualmente, o processo de queima da casca do arroz por leito fluidizado tem sido considerado uma inovação tecnológica que definitivamente permite a obtenção de uma sílica amorfa (SCA) compatível com a necessidade da indústria da construção civil. A adição da SCA junto ao cimento Portland influencia nas propriedades das argamassas tanto no estado fresco quanto endurecido. No estado fresco, a SCA permite reduzir a segregação e a exsudação. Já no estado endurecido, pequenos teores entre $3 \%$ e $8 \%$ permitem aumento de resistência mecânica, diminuição da permeabilidade e maior durabilidade, requisito fundamental para adoção dos parâmetros de sustentabilidade. Desse modo, faz-se importante o estudo da influência da sílica da casca do arroz nas propriedades dos compostos cimentícios.

\section{Resultados e Discussão}

Para o proposto estudo de influência da SCA em compósitos cimentícios foram preparadas em laboratório argamassas de diferentes composições, com diferentes teores de sílica sobre a massa do cimento. Foi estabelecido um traço de referência sem qualquer tipo de incorporação na mistura e com uma relação água/cimento específica. Nota-se, também, que foram feitos dois tipos de incorporação da pozolana em estudo: três composições nas quais a sílica foi apenas adicionada à mistura em percentagens de 5,8 e $10 \%$ sobre a massa de cimento empregado e outras três composições nas quais optou-se pela retirada de diferentes percentagens em massa de cimento e a sua substituição pela sílica da casca do arroz, nos teores de 5,8 e $10 \%$.

Foram realizados ensaios de tempo de pega dos cimentos, determinação do índice de consistência das argamassas pelo método de espalhamento através do uso de um molde tronco-cônico juntamente com a flow table e ensaios mecânicos de tração na flexão e compressão axial.
A análise dos dados de consistência obtidos mostra que não houve uma variação significativa do índice de consistência quando a sílica é adicionada à mistura, o que representa que sua adição pode ser realizada sem que a argamassa sofra perdas consideráveis de trabalhabilidade e consistência.

Quando comparados os valores de rompimento dos corpos de prova da Tabela 1 é possível notar uma melhora significativa na resistência das argamassas que apresentam teores de sílica da casca do arroz. Nota-se que quando a SCA é adicionada à mistura os resultados de resistência, tanto na tração na flexão quanto na compressão axial, são mais expressivos do que os observados na substituição de cimento por sílica.

Por fim, foram analisados os tempos de pega de três tipos de cimento, com e sem a adição em 10\% de SCA. Como os resultados mostraram, não há variações consideráveis nos tempos decorridos de início e fim da pega. Isso representa que mesmo adicionando SCA à mistura não existem complicações na trabalhabilidade da pasta.

Tabela 1. Valores máximos obtidos nos ensaios de tração na flexão e compressão axial.

\begin{tabular}{|c|c|c|}
\hline Traço & $\begin{array}{c}\text { Tração na } \\
\text { Flexão (MPa) }\end{array}$ & $\begin{array}{c}\text { Compressão } \\
\text { Axial (MPa) }\end{array}$ \\
\hline Referência & 6,56 & 35,7 \\
\hline Adição 5\% SCA & 7,70 & 40,9 \\
\hline Adição 8\% SCA & 8,10 & 37,3 \\
\hline Adição 10\% SCA & 7,87 & 41,0 \\
\hline Subst. 5\% SCA & 7,13 & 36,7 \\
\hline Subst. 8\% SCA & 7,36 & 39,3 \\
\hline Subst. 10\% SCA & 7,41 & 38,5 \\
\hline
\end{tabular}

\section{Conclusões}

Os resultados obtidos evidenciam que a SCA influencia nas propriedades dos compósitos cimentícios, especialmente quando são consideradas as propriedades mecânicas dos materiais. Como já era esperado, houve melhoras consideráveis nas resistências a compressão axial e flexão na torção. A manutenção de valores relacionados ao tempo de pega e à consistência das argamassas não estavam previsto, mas isso caracteriza uma manutenção da trabalhabilidade, aspecto importante quando são empregadas adições pozolânicas.

\footnotetext{
${ }^{1}$ GOMES, Carlos Eduardo Marmorato; L.F.M. Marton. MARTON, L.F.M
} Guimarães, Portugal, 2014. - ISSN 2183-1866 